\title{
Analysis of antibiotic resistance phenotypes and genes of Escherichia coli from healthy swine in Guizhou, China
}

\begin{tabular}{|c|c|}
\hline \multicolumn{2}{|c|}{$\begin{array}{l}\text { Authors: } \\
\text { Bo Yu }{ }^{1,2} \text { (D) } \\
\text { Yanan Zhang }^{2} \text { (I) } \\
\text { Li Yang }^{2} \text { (D) } \\
\text { Jinge } \mathrm{Xu}^{2} \\
\text { Shijin } \mathrm{Bu}^{1}\end{array}$} \\
\hline \multicolumn{2}{|c|}{$\begin{array}{l}\text { Affiliations: } \\
{ }^{1} \text { College of Veterinary } \\
\text { Medicine, Yangzhou } \\
\text { University, Yangzhou, China }\end{array}$} \\
\hline \multicolumn{2}{|c|}{$\begin{array}{l}{ }^{2} \text { Institute of Animal } \\
\text { Husbandry and Veterinary } \\
\text { Medicine, Guizhou Academy } \\
\text { of Agricultural Sciences, } \\
\text { Guiyang, China }\end{array}$} \\
\hline \multicolumn{2}{|c|}{$\begin{array}{l}\text { Corresponding author: } \\
\text { Shijin Bu, } \\
\text { sjbo@yzu.edu.cn }\end{array}$} \\
\hline \multicolumn{2}{|c|}{$\begin{array}{l}\text { Dates: } \\
\text { Received: } 11 \text { May } 2020 \\
\text { Accepted: } 09 \text { Dec. } 2020 \\
\text { Published: } 24 \text { Feb. } 2021\end{array}$} \\
\hline \multicolumn{2}{|c|}{$\begin{array}{l}\text { How to cite this article: } \\
\text { Yu, B., Zhang, Y., Yang, L., } \\
\text { Xu, J. \& Bu, S., 2021, } \\
\text { 'Analysis of antibiotic } \\
\text { resistance phenotypes and } \\
\text { genes of Escherichia coli from } \\
\text { healthy swine in Guizhou, } \\
\text { China', Onderstepoort Journal } \\
\text { of Veterinary Research 88(1), } \\
\text { a1880. https://doi.org/ } \\
\text { 10.4102/ojvr.v88i1.1880 }\end{array}$} \\
\hline \multicolumn{2}{|c|}{$\begin{array}{l}\text { Copyright: } \\
\text { (C) 2021. The Authors. } \\
\text { Licensee: AOSIS. This } \\
\text { is licensed under the } \\
\text { Creative Commons } \\
\text { Attribution License. }\end{array}$} \\
\hline \multicolumn{2}{|l|}{ Read online: } \\
\hline 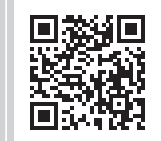 & $\begin{array}{l}\text { Scan this QR } \\
\text { code with your } \\
\text { smart phone or } \\
\text { mobile device } \\
\text { to read online. }\end{array}$ \\
\hline
\end{tabular}

This study was carried out to investigate the resistance phenotypes and resistance genes of Escherichia coli from swine in Guizhou, China. A total of 47 E. coli strains isolated between 2013 and 2018 were tested using the Kirby-Bauer (K-B) method to verify their resistance to 19 common clinical antimicrobials. Five classes consisting of 29 resistance genes were detected using polymerase chain reaction. The status regarding extended-spectrum $\beta$-lactamase (ESBL) and the relationship between ESBL CTX-M-type $\beta$-lactamase genes and plasmid-mediated quinolone resistance (PMQR) genes were analysed. A total of 46 strains (97.9\%) were found to be multidrug resistant. Amongst them, 27 strains (57.4\%) were resistant to more than eight antimicrobials, and the maximum number of resistant antimicrobial agents was 16 . Twenty antibiotic resistance genes were detected, including six $\beta$-lactamase genes blaTEM (74.5\%), blaCTX-M-9G (29.8\%), blaDHA (17.0\%), blaCTX-M-1G (10.6\%), blaSHV (8.5\%), blaOXA (2.1\%), five aminoglycoside-modifying enzyme genes aac(3')-IV (93.6\%), aadA1 (78.7\%), aadA2 (76.6\%), aac(3')-II c (55.3\%), aac(6')-Ib (2.1\%) and five amphenicol resistance genes floR $(70.2 \%), \mathrm{cmlA}$ $(53.2 \%)$, cat2 $(10.6 \%)$, cat1 $(6.4 \%)$, cmlB $(2.1 \%)$, three PMQR genes qnrS $(55.3 \%)$, oqxA $(53.2 \%)$, qepA $(27.7 \%)$ and polypeptide resistance gene mcr-1 $(40.4 \%)$. The detection rate of ESBLpositive strains was $80.9 \%(38 / 47)$ and ESBL TEM-type was the most abundant ESBLs. The percentage of the PMQR gene in blaCTX-M-positive strains was high, and the detection rate of blaCTX-M-9G was the highest in CTX-M type. It is clear that multiple drug resistant $E$. coli is common in healthy swine in this study. Extended-spectrum $\beta$-lactamase is very abundant in the E. coli strains isolated from swine and most of them are multiple compound genotypes.

Keywords: antimicrobial resistance; extended-spectrum $\beta$-lactamase; ESBLs; E. coli from swine; plasmid-mediated quinolone resistance; PMQR; resistance genes.

\section{Background}

Colibacillosis is a common infectious disease in swine caused by pathogenic Escherichia coli, and the main manifestations are sepsis, yellow scour and white scour in piglets. As there are many E. coli serotypes, vaccine-based control is not effective and antimicrobials are the main treatment methods at present (Yan \& Zhao 2018; Zang \& Zhou 2019). With high-dose and wide use of antimicrobials in breeding factories and livestock farms, the multidrug resistant (MDR) problem of bacteria is becoming increasingly serious. Especially, the infection caused by extended-spectrum $\beta$-lactamase (ESBL) producing bacteria increases the difficulty to control and represents a major global public health concern. Escherichia coli with CTX-Ms are the most common species associated with global ESBLs (Peirano \& Pitout 2019). Currently, CTX-M-15 (forming part of the CTX-M-1 subfamily first described in E. coli in 2001 from India [Karim et al. 2001]) is the most frequent CTX-M worldwide. This is closely followed by CTX-M-14 (forming part of the CTX-M-9 subfamily first reported in E. coli, K. pneumoniae and Shigella spp. isolated in Korea in 2001 [Pai et al. 2001]). In the meantime, antibiotic resistance genes (ARGs) carried by E. coli of food animal origin would spread along the food chain and eventually cause harm to the public and human health (Gao, Han \& Guan 2017; Yin, Chen \& Cao 2018). Therefore, it is necessary to monitor the prevalence of drug resistance and ARGs in animals, particularly in swine.

This study investigated the prevalence of resistance phenotypes and resistance genes of E. coli isolated from swine in Guizhou in recent years, analysed ESBL status and the relationship between CTX-M-type $\beta$-lactamase genes and plasmid-mediated quinolone resistance (PMQR) genes. The findings would provide cues for rationale use of antimicrobials in veterinary practice to reduce transmission of drug resistance in the animal. 


\section{Materials and methods}

\section{Escherichia coli strains}

A total of 112 faecal swab samples were collected from 47 large-scale pig farms in 13 counties and cities, including Guiyang, Anshun, Bijie, Qianxinan, Qiandongnan and Qiannan in Guizhou Province between 2013 and 2018. The samples were taken from diseased piglets with yellow and white scour symptoms, streaked out on Mackay medium and cultured at $37{ }^{\circ} \mathrm{C}$ for $24 \mathrm{~h}$. Pink colonies were picked and purified on Luria-Bertani (LB) agar plate at $37{ }^{\circ} \mathrm{C}$ for $24 \mathrm{~h}$, and the plates were stored at $4{ }^{\circ} \mathrm{C}$ for subsequent use. Isolated bacterial strains were cultured in LB medium at $37^{\circ} \mathrm{C}$ for $24 \mathrm{~h}$ and tested according to Bergey's Manual of Systematic Bacteriology. The strains were further classified using $16 \mathrm{~s}$ ribosomal ribonucleic acid (rRNA) sequences, which were sequenced using a pair of universal primers (16S-F, 5'-TGT GGG AAC GGC GAG TCG GAA TAC-3'; 16S-R, 5'-GGG CGC AGG GGA TGA AAC TCA AC-3') (Shahi, Singh \& Kumar 2013).

\section{Reagent and culture medium}

MacConkey agar medium, eosin-methylene blue agar medium, LB broth, LB agar medium, casein hydrolysate agar (MH agar, Muller-Hinton agar), and casein hydrolysate broth ( $\mathrm{MH}$ broth, Muller-Hinton broth) were purchased from Huankai Microbial Technology, Guangzhou; DNA markers and Premix Taq (EX Taq version 2.0 plus dye) were purchased from Takara Bio, Dalian; agarose was purchased from Biowest, Spain. Antimicrobial susceptibility disks were purchased from Binhe Microorganism Reagent, Hangzhou and they were used to test susceptibility to beta-lactam antibiotics beta-lactam antibiotics (cefotaxime 30 micrograms $[\mu \mathrm{g}]$, ceftazidime $30 \mu \mathrm{g}$, cefoxitin $30 \mu \mathrm{g}$, ampicillin $10 \mu \mathrm{g}$, amoxicillin-clavulanate $20 \mu \mathrm{g}$ and $10 \mu \mathrm{g}$ ), aminoglycosides (amikacin $30 \mu \mathrm{g}$, gentamicin $10 \mu \mathrm{g}$, kanamycin $30 \mu \mathrm{g}$, streptomycin $10 \mu \mathrm{g}$, neomycin $30 \mu \mathrm{g}$ ), tetracyclines (tetracycline $30 \mu \mathrm{g}$, doxycycline $30 \mu \mathrm{g}$ ), amphenicols (chloramphenicol $30 \mu \mathrm{g}$, florfenicol $30 \mu \mathrm{g}$ ), fluoroquinolones (ciprofloxacin $5 \mu \mathrm{g}$, enrofloxacin $5 \mu \mathrm{g}$, levofloxacin $5 \mu \mathrm{g}$ ), polymyxin B (300 units) and sulfisoxazole ( $250 \mu \mathrm{g}$ and $300 \mu \mathrm{g})$.

\section{Drug susceptibility test}

The Kirby-Bauer method (K-B method) was used to test the susceptibility to antimicrobials. Escherichia coli ATCC ${ }^{\circledR} 25922$ was used as the quality control strain in antimicrobial susceptibility testing. The breakpoints for tested drugs were used as recommended by the standards and guidelines described by the CLSI (2018b: M100) and veterinary CLSI (VET01-A4/VET01-S2) (CLSI 2018a, 2018b). Based on the test, E. coli was classified as susceptible (S), intermediate (I) and resistant $(\mathrm{R})$.

\section{Test of antibiotic resistance genes Extraction of bacterial deoxyribonucleic acid}

Strains stored at $-80{ }^{\circ} \mathrm{C}$ were inoculated in LB broth for recovery, streaked on eosin-methylene blue agar medium and incubated at $37^{\circ} \mathrm{C}$ overnight. Fresh single colonies on the eosin-methylene blue plate were inoculated in $3 \mathrm{~mL} \mathrm{LB}$ broth and cultured at $37^{\circ} \mathrm{C}$ on a shaker operated at 200 revolutions per minute $(\mathrm{r} / \mathrm{min})$ for $12 \mathrm{~h}$. The culture was then centrifuged at $12000 \mathrm{r} / \mathrm{min}$ for $5 \mathrm{~min}$. Bacterial pellet was suspended in $500 \mu \mathrm{L} 1 \times \mathrm{TE}$, vortexed and boiled for $10 \mathrm{~min}$. Bacterial DNA was extracted using TIANamp Bacterial DNA Extraction Kit (TIANGEN, China) according to manufacturer's instruction.

\section{Polymerase chain reaction}

Polymerase chain reaction (PCR) was used to amplify genes from the E. coli strains, including $\beta$-lactamase genes $\left(b l a_{\mathrm{DHA}}, b l a_{\mathrm{CMY}-2^{\prime}} b l a_{\mathrm{TEM}}, b l a_{\mathrm{SHV}}, b l a_{\mathrm{CTX}-\mathrm{M}-1 \mathrm{G}^{\prime}} b l a_{\mathrm{CTX}-\mathrm{M}-9 \mathrm{G}}, b l a_{\mathrm{OXA}}\right)$, aminoglycoside modifying enzyme genes (aac (3')-Ia, aac (3')IIc, aac( $\left.3^{\prime}\right)-I V$, aac(6')-Ib, aadA1, aadA2, $\left.\operatorname{rmt} A, \operatorname{rmtB}\right)$, amphenicol resistance genes (cat1, cat2, cmlA, cmlB, floR), PMQR genes ( $q n r A, q n r B, q n r C, q n r D, q n r S, q e p A, o q x A, o q x B)$ and polypeptide resistance gene $m c r-1$. The primers for PCR are listed in Table 2 and were synthesised at Sangon Biotech, Shanghai.

Polymerase chain reaction amplification was performed in a final volume of $25 \mu \mathrm{L}$ containing $1 \mu \mathrm{L}$ bacterial DNA, $0.5 \mu \mathrm{L}$ each of primers, $12.5 \mu \mathrm{L}$ Premix Taq (EX Taq version 2.0 plus dye). Parameters for PCR were: initial denaturation for $10 \mathrm{~min}$ at $94{ }^{\circ} \mathrm{C}$, followed by 30 cycles of $45 \mathrm{~s}$ at $94^{\circ} \mathrm{C}, 45 \mathrm{~s}$ at annealing temperature and $1 \mathrm{~min}$ at $72{ }^{\circ} \mathrm{C}$ with a final extension of $10 \mathrm{~min}$ at $72{ }^{\circ} \mathrm{C}$. The annealing temperatures for each pair of primers are listed in Table 1. The amplified PCR products were separated by electrophoresis on a $1 \%$ agarose gel in Trisborate-Ethylenediaminetetraacetic acid (EDTA) buffer (TBE) containing 1\% Goldview Nucleic Acid Gel Stain (Solarbio, Beijing, China) and monitored in gel documentation unit (BioRad Laboratories, United States). The amplicons were sequenced at Sangon Biotech, Shanghai. Sequence alignments were carried out using BLAST on NCBI website http:/ / www. ncbi.nlm.nih.gov/ to determine the genes of interest.

\section{Ethical consideration}

No animal-related tests were involved in this study, and the faecal swab samples were provided by the farm owners who volunteered to participate in the study. The sampling protocols, strain isolation and experiments were conducted in accordance with Section 20 of the Animal Diseases Act of 1984 (Act No. 35 of 1984), Technical Guidelines for Isolation and Identification of Animal Origin Escherichia coli (DB51/T 20842015) and the Declaration of Helsinki, and were approved by the Animal Research Ethics Committee of Institute of Animal Husbandry and Veterinary Medicine, the College of Veterinary Medicine, Yangzhou University, Yangzhou, China.

\section{Results}

\section{Isolated Escherichia coli strains were multidrug resistant}

Drug susceptibility tests showed that 47 E. coli strains isolated from swine had the highest rates of resistance to tetracycline and doxycycline, which were both $95.7 \%(n=45)$, followed 
TABLE 1: Primers for polymerase chain reaction.

\begin{tabular}{|c|c|c|c|c|}
\hline Genes & Primer sequence $\left(5^{\prime}-3^{\prime}\right)$ & Product size (bp) & Annealing temperature $\left({ }^{\circ} \mathrm{C}\right)$ & Reference \\
\hline \multirow[t]{2}{*}{$b l a_{\mathrm{DHA}}$} & F: AACTTTCACAGGTGTGCTGT & 387 & 56 & Pai, Seo \& Choi, 2007 \\
\hline & R: CCGTACGCATACTGGCTTTC & & & \\
\hline \multirow[t]{2}{*}{$b / a_{\mathrm{CMY}-2}$} & F: ATGATGAAAAAATCGTTATGC & 1143 & 55 & Yan et al. 2007 \\
\hline & R: TTGCAGCTTTTCAAGAATGCG & & & \\
\hline \multirow[t]{2}{*}{$b / a_{\text {TEM }}$} & F: ATAAAATTCTTGAAGACGAAA & 1080 & 52 & Weill et al. 2004 \\
\hline & R: GACAGTTACCAATGCTTAATC & & & \\
\hline \multirow[t]{2}{*}{$b l a_{\mathrm{SHV}}$} & F: CACTCAAGGATGTATTGTG & 885 & 55 & Brinas et al. 2005 \\
\hline & R: TTAGCGTTGCCAGTGCTCG & & & \\
\hline \multirow[t]{2}{*}{$b / a_{\mathrm{CTX}-\mathrm{M}-1 \mathrm{G}}$} & F: CTTCCAGAATAAGGAATCCC & 949 & 55 & Liu et al. 2007 \\
\hline & R: CGTCTAAGGCGATAAACAAA & & & \\
\hline \multirow[t]{2}{*}{$b / a_{\text {стX-M-gG }}$} & F: TGACCGTATTGGGAGTTTG & 902 & 58.5 & Liu et al. 2007 \\
\hline & R: ACCAGTTACAGCCCTTCG & & & \\
\hline \multirow[t]{2}{*}{ bla $_{\text {OXA }}$} & F: ATATCTCTACTGTTGCATCTCC & 619 & 48 & Colom et al. 2003 \\
\hline & R: AAACCCTTCAAACCATCC & & & \\
\hline \multirow[t]{2}{*}{ aac $\left(3^{\prime}\right)-1 a$} & F: TTACGCAGCAGCAACGATGT & 402 & 58.5 & Sun et al. 2012 \\
\hline & R: GTTGGCCTCATGCTTGAGGA & & & \\
\hline \multirow[t]{2}{*}{$\operatorname{aac}\left(3^{\prime}\right)-11 c$} & F: AACCGGTGACCTATTGATGG & 774 & 58.5 & Sun et al. 2012 \\
\hline & R: TGTGCTGGCACGATCGGAGT & & & \\
\hline \multirow[t]{2}{*}{$\operatorname{aac}\left(3^{\prime}\right)-\mathrm{IV}$} & F: GGCCACTTGGACTGATCGAG & 609 & 58.5 & Sun et al. 2012 \\
\hline & R: GCGGATGCAGGAAGATCAAC & & & \\
\hline \multirow[t]{2}{*}{$\mathrm{aac}\left(6^{\prime}\right)-\mathrm{lb}$} & F: TTGCGATGCTCTATGAGTGGCTA & 482 & 55 & Park et al. 2006 \\
\hline & R: CTCGAATGCCTGGCGTGTTT & & & \\
\hline \multirow[t]{2}{*}{ aadA1 } & F: AGGTAGTTGGCGTCATCGAG & 589 & 58.5 & Sun et al. 2012 \\
\hline & R: CAGTCGGCAGCGACATCCTT & & & \\
\hline \multirow[t]{2}{*}{$\operatorname{aadA2}$} & F: GGTGCTAAGCGTCATTGAGC & 470 & 51 & Sun et al. 2012 \\
\hline & R: GCTTCAAGGTTTCCCTCAGC & & & \\
\hline \multirow[t]{2}{*}{ rmtA } & F: CTAGCGTCCATCCTTTCCTC & 635 & 55 & Chen et al. 2004 \\
\hline & R: TTGCTTCCATGCCCTTGCC & & & \\
\hline \multirow[t]{2}{*}{$\mathrm{rmtB}$} & F: ACATCAACGATGCCCTCAC & 724 & 54 & Chen et al. 2004 \\
\hline & R: AAGTTCTGTTCCGATGGTC & & & \\
\hline \multirow[t]{2}{*}{ cat1 } & F: CTTGTCGCCTTGCGTATAAT & 508 & 54 & Chen et al. 2004 \\
\hline & R: ATCCCAATGGCATCGTAAAG & & & \\
\hline \multirow[t]{2}{*}{ cat2 } & F: AACGGCAYGATGAACCTGAA & 547 & 50 & Chen et al. 2004 \\
\hline & R: ATCCCAATGGCATCGTAAAG & & & \\
\hline $\mathrm{cmlA}$ & F: CGCCACGGTGTTGTTGTTAT & 394 & 55 & Chen et al. 2004 \\
\hline & R: GCGACCTGCGTAAATGTCAC & & & \\
\hline $\mathrm{cm} / \mathrm{B}$ & F: ACTCGGCATGGACATGTACT & 840 & 55 & Chen et al. 2004 \\
\hline & R: ACGGACTGCGGA ATCCATAG & & & \\
\hline floR & F: CTGAGGGTGTCGTCATCTAC & 673 & 58 & Chen et al. 2004 \\
\hline & R: GCTCCGACAATGCTGACTAT & & & \\
\hline qnrA & F: ATTTCTCACGCCAGGATTTG & 516 & 58 & Robicsek et al. 2006 \\
\hline & R: GATCGGCAAAGGTTAGGTCA & & & \\
\hline qnrB & F: GATCGTGAAAGCCAGAAAGG & 469 & 58 & Robicsek et al. 2006 \\
\hline & R: ACGATGCCTGGTAGTTGTCC & & & \\
\hline qnrC & F: ATTTCTCACAGGCAAACT & 666 & 53 & Sun et al. 2012 \\
\hline & R: CTGGAATAACAATCACCC & & & \\
\hline qnrD & F: TTTTCGCTAACTAACTCGC & 984 & 54.4 & Sun et al. 2012 \\
\hline & R: GAAAGGATAAACAGGCAAAT & & & \\
\hline qnrS & F: ACGACATTCGTCAACTGCAA & 417 & 56 & Robicsek et al. 2006 \\
\hline & R: TAAATTGGCACCCTGTAGGC & & & \\
\hline qepA & F: GCAGGTCCAGCAGCGGGTAG & 199 & 60 & Yamane et al. 2008 \\
\hline & R: CTTCCTGCCCGAGTATCGTG & & & \\
\hline oqxA & F: GATCAGTCAG TGGGATAGTTT & 670 & 52 & Hansen et al. 2005 \\
\hline & R: TACTCGGCGTTAACTGATTA & & & \\
\hline oqxB & F: TTCTCCCCCGGCGGGAAGTAC & 512 & 52 & Kim et al. 2009 \\
\hline & R: CTCGGCCATTTTTGGCGCGTA & & & \\
\hline mcr-1 & F: CGGTCAGTCCGTTTGTTC & 309 & 52.5 & Liu et al. 2016 \\
\hline & R: CTTGGTCGGTCTGTAGGG & & & \\
\hline
\end{tabular}

$b p$, base pairs. 
by resistance to sulfaisoxazole $(89.4 \%, n=42)$, ceftazidime $(70.2 \%, n=33)$, amoxicillin $(63.8 \%, n=30)$, chloramphenicol $(63.8 \%, n=30)$, ampicillin $(61.7 \%, n=29)$, florfenicol $(57.4 \%$, $n=27)$ and kanamycin $(53.2 \%, n=25)$. The rates of resistance to enrofloxacin, gentamicin, polymyxin B and cefotaxime were $46.8 \%(n=22), 40.4 \%(n=19), 38.3 \%(n=18)$ and $31.9 \%$ $(n=15)$, respectively. The strains had relatively lower rates of resistance to ciprofloxacin, levofloxacin, neomycin and streptomycin, which were $29.8 \%(n=14), 29.8 \%(n=14)$, $19.1 \%(n=9)$ and $17.0 \%(n=8)$, respectively. In addition, the tests also showed that the strain had a rate of resistance to cefoxitin at only $8.5 \%(n=4)$, and none of them was resistant to amikacin (Table 2).

When analysed based on isolation time (Table 2), the rates of resistance to ampicillin, amoxicillin, enrofloxacin and levofloxacin increased from 2013 to 2018, whilst the rate of resistance to kanamycin decreased during the same period. On other hand, the rates of resistance to ceftazidime and cefoxitin remained unchanged from 2013 to 2017, and increased in 2018; the rates of resistance to cefotaxime, gentamicin, streptomycin and neomycin were the highest from 2015 to 2017, and decreased in 2018. The rates of resistance of the 47 strains to florfenicol, chloramphenicol, tetracycline, doxycycline and sulfaisoxazole were higher than $50 \%$ from 2013 to 2018 . For polymyxin B, the rate of resistance was 14.3\% (2/14) in 2018, obviously lower than that from 2013 to 2014 (12.8\%) and from 2015 to 2017 (55.6\%, 10/18).

According to the criteria of multidrug resistance test, all 46 strains tested were resistant to more than three classes of antimicrobial agents, indicating serious multidrug resistance in these strains (Figure1). Amongst them, 27 strains were resistant to more than eight antimicrobials, four strains were resistant to 15 antimicrobials, of which,
ECP27 resisted to as many as 16 antimicrobials (Supplementary Table 1).

\section{Antibiotic resistance genes were detected in all isolates}

In this study, 20 ARGs were detected (Table 3) using PCRbased assays and verified by sequencing and sequence alignment with BLASL. They were generally consistent with respective resistance phenotypes. Of which, aac (3')-IV (93.6\%, $n=44)$, aadA1 $(78.7 \%, n=37)$, aadA2 $(76.6 \%, n=36)$, bla ${ }_{\text {TEM }}(74.5 \%, n=35)$, floR $(70.2 \%, n=33)$, qnrS $(55.3 \%$, $n=26), \operatorname{aac}\left(3^{\prime}\right)$-IIc $(55.3 \%, n=26), \operatorname{cmlA}(53.2 \%, n=25)$ and oqxA $(53.2 \%, n=25)$ were prevalent with higher detection rates. Amongst the 47 E. coli strains, 39 strains carried $\beta$-lactamase genes with a detection rate of $83.0 \%$, of which, the detection rates of $b l a_{\mathrm{TEM}^{\prime}} b l a_{\mathrm{DHA}^{\prime}} b l a_{\mathrm{SHV}}$ and $b l a_{\mathrm{OXA}}$ were $74.5 \%$ (35/47), $17.0 \%(8 / 47), 8.5 \%(4 / 47)$ and $2.1 \%(1 / 47)$, respectively. The $b l a_{\mathrm{CMY}-2}$ gene was not detected, the detection rate of $b l a_{\text {СTX-M-9G }}$ in CTX-M was $29.8 \%$ (highest) and the detection rate of $b l a_{\mathrm{CTX-M-1G}}$ was $10.6 \%$. Amongst the strains positive for aminoglycoside-modifying enzyme genes, only one strain was positive for aac $\left(6^{\prime}\right)-I b$. The detection rates of $\operatorname{cmlA}(53.2 \%, 25 / 47)$ and floR $(70.2 \%$, $33 / 47)$ were higher, which were the main causes for amphenicols resistance. Three PMQR genes qnrS, oqxA and qep $A$ were detected at rates of 55.3\% (26/47), 53.2\%, (25/47) and $27.7 \%(13 / 47)$, respectively. In addition, the detection rate of the mobilised colistin resistance gene mcr-1 was $40.4 \%$.

Antibiotic resistance genes were detected in all 47 strains, of which, 28 (59.6\%) strains had more than eight ARGs, nine (19.1\%) strains had more than 10 ARGs, and ECP27 had 14 ARGs (Supplementary Table 1).

TABLE 2: Antibiotic resistance of 47 Escherichia coli isolates over different years.

\begin{tabular}{|c|c|c|c|c|c|c|c|c|}
\hline \multirow[t]{3}{*}{ Antimicrobial agents } & \multirow{2}{*}{\multicolumn{2}{|c|}{ Resistant }} & \multicolumn{6}{|c|}{ Years } \\
\hline & & & \multicolumn{2}{|c|}{$\begin{array}{c}2013-2014 \\
(n=15)\end{array}$} & \multicolumn{2}{|c|}{$\begin{array}{c}2015-2017 \\
(n=18)\end{array}$} & \multicolumn{2}{|c|}{$\begin{array}{c}2018 \\
(n=14)\end{array}$} \\
\hline & $\begin{array}{l}\text { No. resistant } \\
\text { strain }\end{array}$ & $\%$ & $\begin{array}{l}\text { No. resistant } \\
\text { strain }\end{array}$ & $\%$ & $\begin{array}{l}\text { No. resistant } \\
\text { strain }\end{array}$ & $\%$ & $\begin{array}{l}\text { No. resistant } \\
\text { strain }\end{array}$ & $\%$ \\
\hline Cefotaxime & 15 & 31.9 & 4 & 26.7 & 8 & 44.4 & 3 & 21.4 \\
\hline Ceftazidime & 33 & 70.2 & 10 & 66.7 & 12 & 66.7 & 11 & 78.6 \\
\hline Cefoxitin & 4 & 8.5 & 1 & 6.7 & 1 & 5.6 & 2 & 14.3 \\
\hline Amoxicillin-clavulanate & 30 & 63.8 & 8 & 53.3 & 11 & 61.1 & 11 & 78.6 \\
\hline Amikacin & 0 & 0.0 & 0 & 0.0 & 0 & 0.0 & 0 & 0.0 \\
\hline Gentamicin & 19 & 40.4 & 6 & 40.0 & 10 & 55.6 & 3 & 21.4 \\
\hline Kanamycin & 25 & 53.2 & 11 & 73.3 & 8 & 44.4 & 6 & 42.9 \\
\hline Streptomycin & 8 & 17.0 & 2 & 13.3 & 4 & 22.2 & 2 & 14.3 \\
\hline Neomycin & 9 & 19.1 & 2 & 13.3 & 4 & 22.2 & 3 & 21.4 \\
\hline Ciprofloxacin & 14 & 29.8 & 4 & 26.7 & 6 & 33.3 & 4 & 28.6 \\
\hline Levofloxacin & 14 & 29.8 & 4 & 26.7 & 5 & 27.8 & 5 & 35.7 \\
\hline Florfenicol & 27 & 57.4 & 8 & 53.3 & 11 & 61.1 & 8 & 57.1 \\
\hline Chloramphenicol & 30 & 63.8 & 10 & 66.7 & 10 & 55.6 & 10 & 71.4 \\
\hline Tetracycline & 45 & 95.7 & 15 & 100.0 & 16 & 88.9 & 14 & 100.0 \\
\hline Doxycycline & 45 & 95.7 & 14 & 93.3 & 17 & 94.4 & 14 & 100.0 \\
\hline Polymyxin B & 18 & 38.3 & 6 & 40.0 & 10 & 55.6 & 2 & 14.3 \\
\hline Sulfisoxazole & 42 & 89.4 & 14 & 93.3 & 15 & 83.3 & 13 & 92.9 \\
\hline
\end{tabular}




\begin{tabular}{|c|c|c|}
\hline \multirow{2}{*}{$\begin{array}{l}\text { Antibiotic resistance } \\
\text { genes }\end{array}$} & \multicolumn{2}{|c|}{ Detection rate } \\
\hline & No. positive strain & $\%$ \\
\hline \multicolumn{3}{|l|}{$\beta$-lactamase } \\
\hline$b / a_{\mathrm{DHA}}$ & 8 & 17.0 \\
\hline$b l a_{\mathrm{TEM}}$ & 35 & 74.5 \\
\hline$b l a_{\mathrm{SHV}}$ & 4 & 8.5 \\
\hline$b / a_{\text {CTX-M-1G }}$ & 5 & 10.6 \\
\hline$b / a_{\mathrm{CTX}-\mathrm{M}-9 \mathrm{G}}$ & 14 & 29.8 \\
\hline$b / a_{\mathrm{O} \times \mathrm{A}}$ & 1 & 2.1 \\
\hline \multicolumn{3}{|c|}{ Aminoglycoside-modifying enzyme gene } \\
\hline $\operatorname{aac}\left(3^{\prime}\right)-11 c$ & 26 & 55.3 \\
\hline $\operatorname{aac}\left(3^{\prime}\right)-I V$ & 44 & 93.6 \\
\hline$a a c\left(6^{\prime}\right)-1 b$ & 1 & 2.1 \\
\hline $\operatorname{aadA1}$ & 37 & 78.7 \\
\hline $\operatorname{aad} A 2$ & 36 & 76.6 \\
\hline \multicolumn{3}{|c|}{ Amphenicol resistance genes } \\
\hline cat1 & 3 & 6.4 \\
\hline cat2 & 5 & 10.6 \\
\hline $\mathrm{cm} / \mathrm{A}$ & 25 & 53.2 \\
\hline $\mathrm{cm} / \mathrm{B}$ & 1 & 2.1 \\
\hline floR & 33 & 70.2 \\
\hline \multicolumn{3}{|l|}{ PMQR } \\
\hline qnrs & 26 & 55.3 \\
\hline qepA & 13 & 27.7 \\
\hline oqxA & 25 & 53.2 \\
\hline \multicolumn{3}{|c|}{ MobiliSed colistin resistance gene } \\
\hline$m c r-1$ & 19 & 40.4 \\
\hline
\end{tabular}

PMQR, plasmid-mediated quinolone resistance.

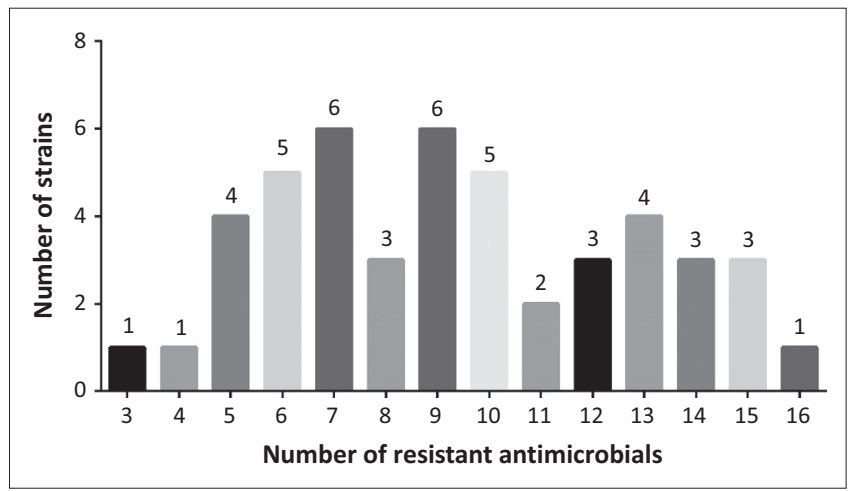

FIGURE 1: Distribution of Escherichia coil strains resistant to antimicrobials.

\section{Various extended-spectrum $\beta$-lactamase genes were present in the isolates}

Amongst the 47 strains tested, 38 (80.9\%) strains carried ESBLS and 20 of them harbored various number of ESBLs. The most frequent was $b l a_{\mathrm{TEM}}+b l a_{\mathrm{CTX}-\mathrm{M}-9 \mathrm{G}}(26.3 \%, 10 / 38)$; three strains were found to have three ESBLs genes and ECP27 had four ESBLs genes $b l a_{\mathrm{TEM}^{\prime}} b l a_{\mathrm{CTX}-\mathrm{M}-1 \mathrm{G}^{\prime}} b l a_{\mathrm{CTX}-\mathrm{M}-9 \mathrm{G}}$ and $b l a_{\mathrm{SHV}}$ (Figure 2, Supplementary Table 1).

\section{Various plasmid-mediated quinolone resistance genes were detected in CTX-M positive strains}

We analysed the PMQR genes in 17 strains carrying $b l a_{\text {СтХ-M }}$ and the results are shown in Figure 3. The PMQR genes were found in 14 strains, including strains with two genes $b l a_{\mathrm{CTX}-\mathrm{M}-9 \mathrm{G}}+q n r S$ (two strains), $b l a_{\mathrm{CTX}-\mathrm{M}-9 \mathrm{G}}+o q x A$ (two strains), $b l a_{\mathrm{CTX}-\mathrm{M}-1 \mathrm{G}}+q h r S$ (one strain) and $b l a_{\mathrm{CTX}-\mathrm{M}-1 \mathrm{G}}+q e p A$ (one strain), three genes bla ${ }_{\text {СтХ-M-9G }}+q n r S+o q x A$ (four strains), $b l a_{\text {СтХ-M-9G }}+$

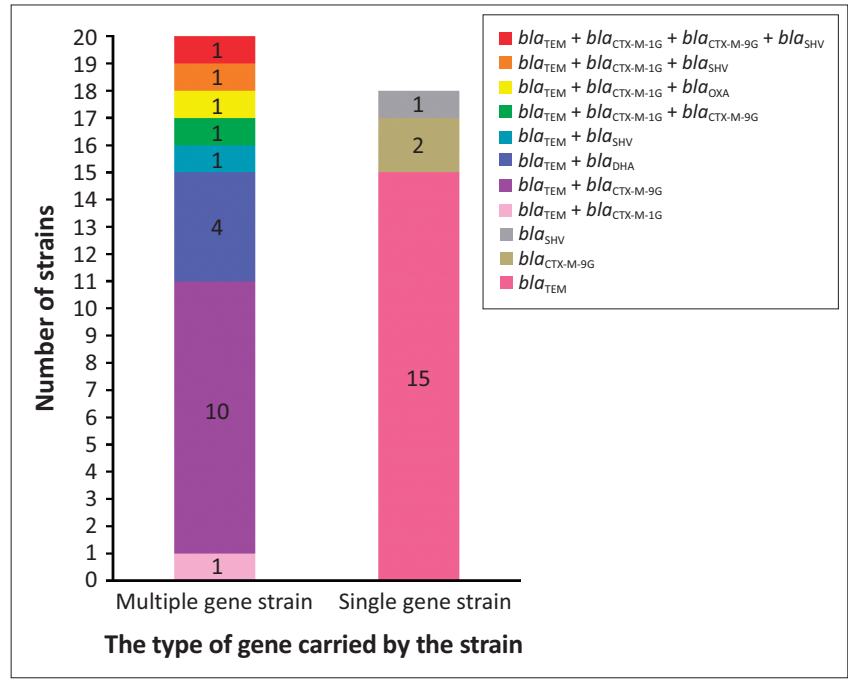

FIGURE 2: Genetic compositions of extended-spectrum $\beta$-lactamase strains. Left column: multiple gene strains, Right column: single gene strains.

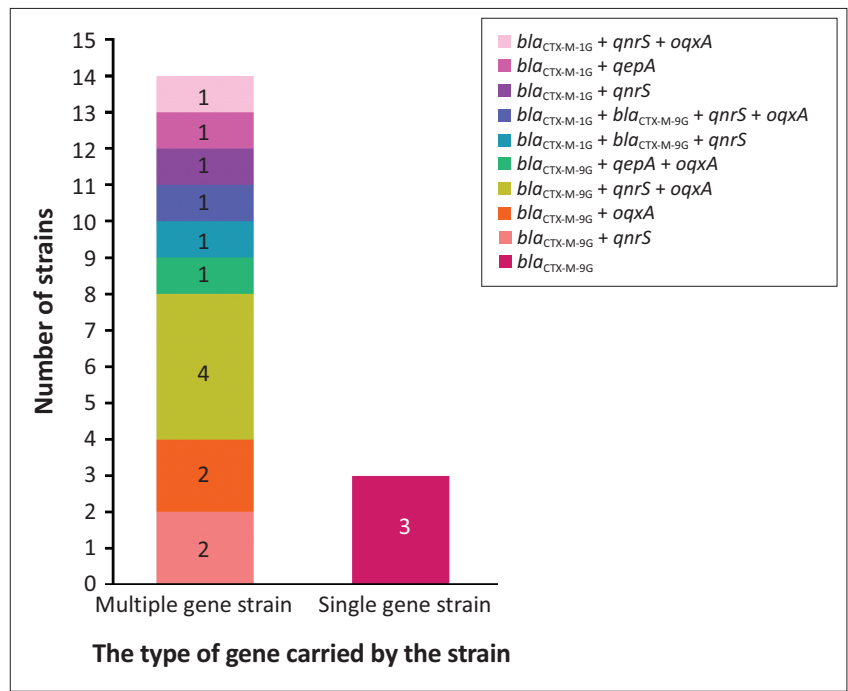

FIGURE 3: Genetic compositions of CTX-M positive strains. Left column: multiple gene strains, Right column: single gene strains.

qер $A+$ oqx $A$ (one strain), bla $a_{\text {СТх-M-1 }}+b l a_{\text {СТх-M-9G }}+q n r S$ (one strain) and $b l a_{\mathrm{CTX}-\mathrm{M}-1 \mathrm{G}}+q n r S+o q x A$ (one strain) and four genes $b l a_{\mathrm{CTX}-\mathrm{M}-}$ ${ }_{1 \mathrm{G}}+b l a_{\mathrm{CTX}-\mathrm{M}-9 \mathrm{G}}+q n r S+o q x A$ (one strain), of which, $b l a_{\mathrm{CTX}-\mathrm{M}-9 \mathrm{G}}+$ $q \eta r S+o q x A$ were the most frequent $(23.5 \%, 4 / 17)$.

\section{Discussion}

We investigated 47 E. coli strains isolated from swine in Guizhou from 2013 to 2018 for their resistance to 21 common antimicrobial agents. The results showed serious multidrug resistance in this region. The isolated strains have the highest resistance to the tetracycline antimicrobials, which are comparable to the rates of resistance to tetracycline (97.6\%) and doxycycline (89.3\%) in E. coli from swine in Guizhou in 2018 (Wang \& Tan 2018). The rate of resistance to sulfaisoxazole is $89.4 \%$, which is close to the rate of resistance to sulfonamide antimicrobials in 2018 (Kou, Liu \& Tan 2018). The results may be related to the long-term irrational use of these three antibiotics in the prevention and treatment of piglet respiratory diseases and bacterial diarrhoea in pig breeding in Guizhou. 
The strains are also resistant to $\beta$-lactam drugs, the rates of resistance to third-generation cephalosporin ceftazidime and cefotaxime were $70.2 \%$ and $31.9 \%$, respectively, which were higher than that of second-generation cephalosporin drug cefoxitin (8.5\%). This may be attributed to the irrational use of third-generation cephalosporins and the less use of secondgeneration cephalosporins in the pig farms in Guizhou in recent years.

For aminoglycoside resistance, the highest rates were resistant to kanamycin and gentamicin, followed by neomycin and streptomycin. However, none of the strain is resistant to amikacin. These results are consistent with earlier reports for Guangxi (Ge, Shi \& Hu 2019), Chongqing (Chen \& Liao 2019), Fujian (Yang, Luo \& Xie 2018) and southeastern Shanxi (Shen, Kong \& Guo 2019). This could be because of the less use of amikacin in the pig farms for disease treatment and prevention in Guizhou. The rates of resistance to aminoglycoside gentamicin, streptomycin, ciprofloxacin (a fluoroquinolone antimicrobial agent) and polymyxin (a polypeptide antimicrobial agent) are obviously lower than the rates of resistance (gentamicin $81.10 \%$, streptomycin $53.66 \%$, ciprofloxacin $53.05 \%$ and polymyxin $51.83 \%$ ) observed in Guizhou in 2016 (Cao, Tan \& Liu 2016), whilst the rate of resistance to florfenicol (an amphenicol agent) is obviously higher than previously reported rate (Cao et al. 2016). It is likely that the irrational use of fluorophenicol in the pig farms in recent years and the less use of gentamicin, streptomycin and polymyxins are responsible for the situation. At the same time, the reduction in ciprofloxacin resistance rate may be related to China's ban on the use of four antibiotics in aquaculture from 2016, as well as improved management of livestock form and changes of antimicrobials used and administration method of antimicrobials.

From 2 to 14 ARGs are detected in various stains and over a half of the strains are found to have more than eight resistance genes, indicating that the proportion and quantity of ARGs are high in these strains and the drug resistance problem is serious. In this study, five amphenicols resistant genes were detected, of which, floR $(70.2 \%, 33 / 47)$ and $\mathrm{cmlA}$ $(53.2 \%, 25 / 47)$ genes are frequent, which are believed to be the main cause of amphenicol resistance in the strains. The detection rates of four aminoglycoside-modifying enzyme genes (aac(3')-IV, aadA1, aadA2, aac(3')-IIc) are higher than $50 \%$, and multiple aminoglycoside modifying enzyme genes are detected in the same strains, resulting in high-level resistance to aminoglycosides. In this study, the detection rates of aminoglycosides resistance genes are basically consistent with the resistance phenotypes. However, five aac $\left(3^{\prime}\right)-I V$ positive strains are found susceptible to aminoglycosides, probably because of infective expression of the gene in these strains. $m c r-1 i$ is also frequently found in the strains. $m c r-1 i$ is present in plasmid and chromosome, but mainly plasmids. Plasmids could carry multiple ARGs (Zhu 2019). The high detection rate $(40.4 \%$ ) of $m c r-1$ in this study likely results from overdose use of polymyxins in pig feed in Guizhou.
At present, the resistance of Gram-negative bacteria to $\beta$-lactam drugs is increasingly higher, and the most common resistance mechanism is that bacteria can produce three metalloenzymes: ESBL, cephalosporinase (AmpC enzyme) and carbapenems (Meini et al. 2019). The first two enzymes are the main causes for drug resistance of $E$. coli from livestock and poultry. This study detected five $\beta$-lactamase genes (the detection rate is 83.0\%), including four ESBL genes $\left(b l a_{\mathrm{TEM}^{\prime}}, b l a_{\mathrm{CTX}_{\mathrm{M}}{ }^{\prime}}, b l a_{\mathrm{SHV}}, b l a_{\mathrm{OXA}}\right)$ and one AmpC enzyme gene $\left(b l a_{\mathrm{DHA}}\right)$. There are $38(80.9 \%)$ E. coli strains that produce ESBL, and these strains are more frequent to be resistant to various antimicrobials than the other nine strains that do not produce ESBLs. Extended-spectrum $\beta$-lactamase -positive strains can produce $\beta$-lactamase to hydrolyse $\beta$-lactamase antibiotics, it often leads to clinical failure of infection treatment. In the previous reports, CTX-M-type was most prevalent in ESBLs (Ho et al. 2011; Jiang, Kui \& Huang 2015; Yang, Zeng \& Lin 2019; Zeng 2016), but in this study, bla $a_{\text {TEM }}$ is the most popular in 38 ESBLs-positive strains $(89.7 \%$, $35 / 38)$, and it is basically consistent with the detection rate of $90.51 \%$ in Guizhou in 2016 (Cao et al. 2016), which should be taken seriously. bla $a_{\text {СТХ-M-9G }}$ is most prevalent amongst CTX-Ms in this study (29.8\%), conforming to the prevalence situation reported in this country (Jiang et al. 2015; Yang et al. 2019). Amongst 38 bacterial strains carrying ESBLs genes, eight complex ESBLs genotypes are detected, of which, the proportion of $b l a_{\mathrm{TEM}}+b l a_{\mathrm{CTX}-\mathrm{M}-9 \mathrm{G}}$ is the highest $(26.3 \%, 10 / 38)$. Furthermore, coexistence of $b l a_{\text {CTX-M-1G }}$ and bla ${ }_{\text {CTX-M-9G }}$ are found in ECP4 and ECP27, which carried four ESBLs genes. These findings showed that ESBLs genotypes are complex in the E. coli strains in Guizhou and would result in clinical challenges for infection control.

Low-resistant PMQR genes conferring quinolone resistances are shown to be closely related to the prevalence of ESBLs (Ma et al. 2009; Wu et al. 2007; Yang, Zhuang \& Hua 2018), especially $q n r / \operatorname{oq} x A B$ and $b l a_{\text {СтХ-м }}$ genes, which may be located on the same plasmid (Liu et al. 2014; Strahilevitz et al. 2009). In this study, PMQR genes were analysed in 17 E. coli strains and 14 strains were found to have $b l a_{\text {СтХ-м }}$ with a detection rate of $82.4 \%$, of which, qnrS and oqxA are detected at $58.8 \%$ and $52.9 \%$ of the strains. The complex genotype $b l a_{\text {СТХ-M-9G }}+q n r S+o q x A$ is detected in four strains. It is, therefore, likely that the ESBLs and PMQR genes are located on the same plasmid in the E. coli stains, which would somewhat increase the risk of horizontal transmission of ARGs. Previously, it was shown that oqxA and oqxB frequently coexist (Yang et al. 2018). However, this coexistence was not observed in our study, and further study is needed to clarify the situation.

\section{Conclusion}

Extended-spectrum $\beta$-lactamase is widespread in E. coli from pigs in Guizhou and TEM-type is the most prevalent ESBLs. Most of the E. coli strains have multiple ESBLs. In CTX-M strains, CTX-M-9G is the most frequent; PMQR carriers are often detected in $b l a_{\mathrm{CTX}-\mathrm{M}}$-positive strains, and 
the two genes are likely located on the same plasmids. Therefore, the co-transmission needs to be addressed in the future. Only oqxA was detected but not oqxB in this study, indicating a need to clarify their relationship. Co-existence of $b l a_{\mathrm{TEM}}+b l a_{\mathrm{CTX}-\mathrm{M}-1 \mathrm{G}}+b l a_{\mathrm{CTX}-\mathrm{M}-9 \mathrm{G}}$ in ECP 4 and $b l a_{\mathrm{TEM}}+b l a_{\mathrm{CTX}-\mathrm{M}-1 \mathrm{G}}+$ $b l a_{\mathrm{CTX}-\mathrm{M}-9 \mathrm{G}}+b l a_{\mathrm{SHV}}$ in ECP27 may allow further investigation of the position and position effect. In addition, over $40 \%$ strains are found to contain $m c r-1$, and the location of the gene needs to be defined.

\section{Acknowledgements}

We thank all of the staff at the Guizhou Hongyu Animal Husbandry Technology Development Co., Ltd, who were involved in the response to this event but are not listed as authors.

\section{Competing interests}

The authors have declared that no competing interests exist.

\section{Authors' contributions}

B.Y., Y.Z. and S.B. deigned the study. B.Y., Y.Z., L.Y. and S.B. analysed and interpreted the experimental data. Y.Z., L.Y. and J.X. performed the statistical analysis. L.Y., J.X. and S.B. were major contributors in writing the manuscript. All authors read and approved the final manuscript.

\section{Funding information}

This study was funded by the Priority Academic Program Development of Jiangsu Higher Education Institutions (PAPD), Jiangsu Co-innovation Center for Prevention and Control of Important Animal Infectious Diseases and Zoonoses, Yangzhou, 225009), Animal Epidemic Disease Observation and Monitoring of Guizhou Agricultural Fundamental and Long-Term Science and Technology Work (GZNYKXSYZ-06, QNKYJCXGYXZX [2020] No. 11).

\section{Data availability statement}

The datasets used and/or analysed during this study are available from the corresponding author on reasonable request.

\section{Disclaimer}

The views and opinions expressed in this article are those of the authors and do not necessarily reflect the official policy or position of any affiliated agency of the authors.

\section{References}

Brinas, L., Moreno, M.A., Teshager, T., Saenz, Y., Porrero, M.C., Dominguez, L. et al., 2005, 'Monitoring and characterization of extended-spectrum beta-lactamases in Escherichia coli strains from healthy and sick animals in Spain in 2003', Antimicrobial Agents and Chemotherapy 49(3), 1262-1264. https://doi. org/10.1128/AAC.49.3.1262-1264.2005

Cao, M., Tan, A. \& Liu, S., 2016, 'Resistance analysis and ESBLs genotype detection of Escherichia coli from swine in some regions of Guizhou', China Animal Husbandry \& Veterinary Medicine 43(4), 1098-1104.
Chen, S., Zhao, S., White, D.G., Schroeder, C.M., Lu, R., Yang, H. et al., 2004, 'Characterization of multiple-antimicrobial-resistant salmonella serovars isolated from retail meats', Applied and Environmental Microbiology 70(1), 1-7. https:// doi.org/10.1128/AEM.70.1.1-7.2004

Chen, Y. \& Liao, M., 2019, 'The epidemiological investigation and drug resistance analysis of Escherichia coli from poultry in Chongqing from 2016 to 2017', Chinese Journal of Preventive Veterinary Medicine 41(1), 24-28.

CLSI, 2018a, Performance standard for antimicribial disk and dilution susceptibility tests for bacteria isolated from animals, 4th ed edn., Clinical and Laboratory Standards Institute, Wayne, PA.

CLSI, 2018b, Performance standard for antimicribial susceptibility testing, 28th edn., CLSI supplement M100, CLSI PSfASTteCsM (ed.), Clinical and Laboratory Standards Institute, Wayne, PA.

Colom, K., Perez, J., Alonso, R., Fernandez-Aranguiz, A., Larino, E. \& Cisterna, R., 2003, 'Simple and reliable multiplex PCR assay for detection of blaTEM, bla(SHV) and blaOXA-1 genes in Enterobacteriaceae', FEMS Microbiology Letters 223(2), 147-151. https://doi.org/10.1016/S0378-1097(03)00306-9

Gao, H., Han, J. \& Guan, D., 2017, 'The grim situation of drug resistance in Escherichia coli', Chinese Bulletin of Life Sciences 29(5), 514-520

Ge, C., Shi, D. \& Hu, W., 2019, 'Analysis of virulence factors and multidrug resistance of enterotoxin-producing Escherichia coli from swine in Guangxi', China Animal Husbandry \& Veterinary Medicine 46(3), 913-923.

Hansen, L.H., Sorensen, S.J., Jorgensen, H.S. \& Jensen, L.B., 2005, 'The prevalence of the OqxAB multidrug efflux pump amongst olaquindox-resistant Escherichia col in pigs', Microbial Drug Resistance 11(4), 378-382. https://doi.org/10.1089/ mdr.2005.11.378

Ho, P.L., Chow, K.H., Lai, E.L., Lo, W.U., Yeung, M.K., Chan, J. et al., 2011, 'Extensive dissemination of CTX-M-producing Escherichia coli with multidrug resistance to "critically important" antibiotics among food animals in Hong Kong, 2008-10" Journal of Antimicrobial Chemotherapy 66(4), 765-768. https://doi.org/10.1093/ $\mathrm{jac} / \mathrm{dkq539}$

Jiang, H., Kui, L. \& Huang, H., 2015, 'Class I integron and its correlation with genes coding for ESBLs in ESBLs-producing Escherichia coli from children', Journal of Clinical Pediatrics 33(4), 345-347.

Karim, A., Poirel, L., Nagarajan, S. \& Nordmann, P., 2001, 'Plasmid-mediated extendedspectrum beta-lactamase (CTX-M-3 like) from India and gene association with insertion sequence ISEcp1', FEMS Microbiology Letters 201(2), 237-241. https:// insertion sequence ISEcp1, FEM Microbiolog
doi.org/10.1111/j.1574-6968.2001.tb10762.x

Kim, H.B., Wang, M., Park, C.H., Kim, E.C., Jacoby, G.A. \& Hooper, D.C., 2009, 'oqxAB encoding a multidrug efflux pump in human clinical isolates of Enterobacteriaceae' Antimicrobial Agents and Chemotherapy 53(8), 3582-3584. https://doi.org/ 10.1128/AAC.01574-08

Kou, H., Liu, S. \& Tan, A., 2018, 'Resistance to sulfonamides and resistance genes test of Escherichia coli from swine in Guizhou', Chinese Journal of Veterinary Medicine 54(9), 75-78.

Liu, B.T., Li, L., Fang, L.X., Sun, J., Liao, X.P., Yang, Q.E. et al., 2014, 'Characterization of plasmids carrying oq $\times A B$ in bla(CTX-M)-negative Escherichia coli isolates from food-producing animals', Microbial Drug Resistance 20(6), 641-650. https://doi. org/10.1089/mdr.2014.0022

Liu, J.H., Wei, S.Y., Ma, J.Y., Zeng, Z.L., Lu, D.H., Yang, G.X. et al., 2007, 'Detection and characterisation of CTX-M and CMY-2 beta-lactamases among Escherichia col isolates from farm animals in Guangdong Province of China', International Journa of Antimicrobial Agents 29(5), 576-581. https://doi.org/10.1016/j.ijantimicag. 2006.12.015

Liu, Y.Y., Wang, Y., Walsh, T.R., Yi, L.X., Zhang, R., Spencer, J. et al., 2016, 'Emergence of plasmid-mediated colistin resistance mechanism MCR-1 in animals and human beings in China: A microbiological and molecular biological study', Lancet Infectious Diseases 16(2), 161-168. https://doi.org/10.1016/S1473 3099(15)00424-7

Ma, J., Zeng, Z., Chen, Z., Xu, X., Wang, X., Deng, Y. et al., 2009, 'High prevalence of plasmid-mediated quinolone resistance determinants qnr, aac $\left(6^{\prime}\right)-\mathrm{lb}-\mathrm{cr}$, and qepA among ceftiofur-resistant Enterobacteriaceae isolates from companion and foodproducing animals', Antimicrobial Agents and Chemotherapy 53(2), 519-524. producing animals', Antimicrobial Agents
$\mathrm{https} / / /$ doi.org/10.1128/AAC.00886-08

Meini, S., Tascini, C., Cei, M., Sozio, E. \& Rossolini, G.M., 2019, 'AmpC beta-lactamaseproducing Enterobacterales: What a clinician should know', Infection 47(3) 363-375. https://doi.org/10.1007/s15010-019-01291-9

Pai, H., Choi, E.H., Lee, H.J., Hong, J.Y. \& Jacoby, G.A., 2001, 'Identification of CTX-M-14 extended-spectrum beta-lactamase in clinical isolates of Shigella sonnei, Escherichia coli, and Klebsiella pneumoniae in Korea', Journal of Clinical Microbiology 39(10), 3747-3749. https://doi.org/10.1128/JCM.39.10.37473749.2001

Pai, H., Seo, M.R. \& Choi, T.Y., 2007, 'Association of QnrB determinants and production of extended-spectrum beta-lactamases or plasmid-mediated AmpC betalactamases in clinical isolates of Klebsiella pneumoniae', Antimicrobial Agents and Chemotherapy 51(1), 366-368. https://doi.org/10.1128/AAC.00841-06

Park, C.H., Robicsek, A., Jacoby, G.A., Sahm, D. \& Hooper, D.C., 2006, 'Prevalence in the United States of aac $\left(6^{\prime}\right)$-lb-cr encoding a ciprofloxacin-modifying enzyme', Antimicrobial Agents and Chemotherapy 50(11), 3953-3955. https://doi. org/10.1128/AAC.00915-06

Peirano, G. \& Pitout, J.D.D., 2019, 'Extended-spectrum beta-lactamaseproducing Enterobacteriaceae: Update on molecular epidemiology and treatment options', Drugs 79(14), 1529-1541. https://doi.org/10.1007/ s40265-019-01180-3

Robicsek, A., Strahilevitz, J., Sahm, D.F., Jacoby, G.A. \& Hooper, D.C., 2006, 'qnr prevalence in ceftazidime-resistant Enterobacteriaceae isolates from the United States', Antimicrobial Agents and Chemotherapy 50(8), 2872-2874. https://doi. org/10.1128/AAC.01647-05 
Shahi, S.K., Singh, V.K. \& Kumar, A., 2013, 'Detection of Escherichia coli and associated beta-lactamases genes from diabetic foot ulcers by multiplex PCR and molecular modeling and docking of SHV-1, TEM-1, and OXA-1 beta-lactamases with clindamycin and piperacillin-tazobactam', PLOS One 8(7), e68234. https://doi. org/10.1371/journal.pone.0068234

Shen, Z., Kong, Q. \& Guo, D., 2019, 'Serotyping and drug susceptibility test of Escherichia coli from swine in southeastern Shanxi Province', Chinese Journal of Animal Infectious Diseases 27(1), 96-99.

Strahilevitz, J., Jacoby, G.A., Hooper, D.C. \& Robicsek, A., 2009, 'Plasmid-mediated quinolone resistance: A multifaceted threat', Clinical Microbiology Reviews 22(4), 664-689. https://doi.org/10.1128/CMR.00016-09

Sun, N., Liu, J.H., Yang, F., Lin, D.C., Li, G.H., Chen, Z.L. et al., 2012, 'Molecular characterization of the antimicrobial resistance of Riemerella anatipestife isolated from ducks', Veterinary Microbiology 158(3-4), 376-383. https://doi. org/10.1016/j.vetmic.2012.03.005

Wang, X. \& Tan, A.S.L., 2018, 'Detection of resistance and resistance genes of Escherichia coli from swine to tetracyclines in Guizhou', China Animal Husbandry \& Veterinary Medicine 45(5), 1367-1373.

Weill, F.X., Demartin, M., Tande, D., Espie, E., Rakotoarivony, I. \& Grimont, P.A., 2004 'SHV-12-like extended-spectrum-beta-lactamase-producing strains of Salmonella enterica serotypes Babelsberg and Enteritidis isolated in France among infants adopted from Mali', Journal of Clinical Microbiology 42(6), 2432-2437. https:// doi.org/10.1128/JCM.42.6.2432-2437.2004

Wu, J.J., Ko, W.C., Tsai, S.H. \& Yan, J.J., 2007, 'Prevalence of plasmid-mediated quinolone resistance determinants QnrA, QnrB, and QnrS among clinical isolates of Enterobacter cloacae in a Taiwanese hospital', Antimicrobial Agents and Chemotherapy 51(4), 1223-1227. https://doi.org/10.1128/AAC.01195-06
Yamane, K., Wachino, J., Suzuki, S. \& Arakawa, Y., 2008, 'Plasmid-mediated qepA gene among Escherichia coli clinical isolates from Japan', Antimicrobial Agents and Chemotherapy 52(4), 1564-1566. https://doi.org/10.1128/AAC.01137-07

Yan, J.J., Hong, C.Y., Ko, W.C., Chen, Y.J., Tsai, S.H., Chuang, C.L. et al., 2004, 'Dissemination of blaCMY-2 among Escherichia coli isolates from food animals, retail ground meats, and humans in southern Taiwan', Antimicrobial Agents and Chemotherapy 48(4), 1353-1356. https://doi.org/10.1128/AAC.48.4.1353-1356.2004

Yan, Y. \& Zhao, R. \& Miao, S., 2018, 'Drug susceptibility test and drug resistance gene detection of pig source Escherichia coli', Progress in Veterinary Medicine 39(7), 42-46.

Yang, S., Luo, Z. \& Xie, Y., 2018, 'Aminoglycosides susceptibility assay and rmtB resistance genes epidemic analysis of Escherichia coli from swine', Heilongjiang resistance genes epidemic analysis of Escherichia co
Animal Science and Veterinary Medicine 17, 120-125.

Yang, S., Zeng, X. \& Lin, M., 2019, 'Analysis of antimicrobial resistance of Escherichia coli from swine and extended spectrum $\beta$-lactamases prevalence', Chinese Journal of Zoonoses 35(1), 45-50.

Yang, S., Zhuang, Yi, C. \& Hua, X., 2018, 'Investigation of bla $a_{\text {CTX-M-9G }}$ resistance gene in Escherichia coli isolated from pig origin in the west of Fujian Province', Chinese Veterinary Science 48(5), 658-663.

Yin, Y., Chen, H. \& Cao, L., 2018, 'Research progress in strategies to combat antimicrobial resistance', Chinese Journal of Biotechnology 34(5), 1346-1360.

Zang, M. \& Zhou, L.K.L., 2019, 'Analysis of drug resistance and genetic polymorphism of Escherichia coli isolated from swine in north of Henan Province', Chinese Journal of Veterinary Drug 53(4), 16-22.

Zeng, L., 2016, 'Molecular epidemiologic study on ESBLs genes in Escherichia coli from different origins', Journal of South China Agricultural University 22(3), 22-28.

Zhu, Y., 2019, 'The study on epidemiology and transmission mechanism of polymyxin resistance gene mcr-1 in Escherichia coli from animal origin', Chinese Academy of Agricultural Sciences 232(1), 123-127. 